\title{
GIS Based Method for Flood Hazard Assesment in Kobe River Watershed - North Maluku Province
}

\author{
Nani $\mathrm{Nagu}^{1}$, Lita A. Latif ${ }^{2}$, Bebi $\mathrm{H}^{3}$, And Nurhalis Wahiddin ${ }^{4}$ \\ ${ }^{1}$ Civil Department, Engineering Faculty, Khairun University, 97718, Ternate, Indonesia \\ ${ }^{2}$ Mechanical Department, Engineering Faculty, Khairun University, 97718, Ternate, Indonesia \\ ${ }^{3}$ North Moluccas River Basin Office, 97716 , Ternate, Indonesia \\ ${ }^{4}$ Marine Resources Management, Fisheries and Marine Faculty, Khairun University, 97718, Ternate, Indonesia
}

\begin{abstract}
The objectives of this study are to mapping the hazard-prone area and to analyse the flood vulnerability index in Kobe Watershed, Central Halmahera District. In order to determine the optimal selection of weights for the factors that contribute to flood risk, GIS and multi-criteria decision analysis (MCDA) were used in conjunction with the application of the analytical hierarchy process (AHP) method to create the flood hazard map. The flood hazard map was generated by using selected hazard factors including land use, topography, slope, and rainfall pattern. The result shows that the Kobe River basin is a flood-prone area, with 77.46 percent of its land classified as less prone to flooding and 21.41 percent classified as flood-prone. However, only 21.41 percent of its land is classified as flood-prone. Only 1.13 percent of the land is protected from the danger of floods, compared to the whole country. The altitude factor is the most important element influencing flood susceptibility in Weda District, where the majority of the land (16.34 percent) is located at or below sea level, making it particularly vulnerable to flooding.
\end{abstract}

Keywords: Kobe River Basin; Flood Hazard Assessment; GIS

\section{Introduction}

In many parts of the world, flood is the leading cause of losses from natural phenomena and is responsible for a greater number of damaging events than any other type of natural hazard [1]. Floods may lead to more deaths, relocation of people, loss of livelihoods and property, and environmental degradation, all of which can jeopardize economic growth [2]. Indeed, floods mostly affect susceptible regions as a result of human activity and natural occurrences [3][4]. Human actions such as land use changes and environmental degradation caused by deforestation and commercial logging are responses to flood events. While floods are caused by natural occurrences such as heavy rainfall, sea level rise, and storms as a result of climate change. Increased rainfall as a result of future climate change is predicted to intensify flood occurrences [5].

Flooding is one of the most common catastrophes in North Maluku province, according to statistics from the National Disaster Management Agency for 2020. All areas and cities in this province are classified as very dangerous. Unfortunately, research on flood disasters in this province is still very limited. Some of the studies that have been done such as [6] about Flood Disposal Analysis of The Uru Ino River, East Halmahera Regency Using Synthetic Unit Hydrograph Approach
(HSS) Gamma I And HSS Nakayasu; [7] about Flood Vulnerability Analysis in The Mede Watershed Region, North Halmahera Regency; [8] about Normalization of The Aru River to Complete Flood In Galela District, North Halmahera Regency; [9] about Use Of Hec-HMS To Delineate River Watershed Causes Flooding In The Kelurahan Rua Sub-District Of Ternate Island City Of Ternate; and [10] about Evaluation of The Tugurara River's Cross-Crossing Capacity For Flood Disposal In The City Of Ternate. most of the research was conducted in relation to flood disasters in urban districts in North Maluku, however, the Kobe-river in Central Halmahera district of this type of research is still lacking. Whereas, [11] said that the floods in the Central Halmahera area had been a major catastrophe on a yearly basis.

Floods, on the other hand, leave a temporal and geographic imprint that indicates the length of their effect and their extent on the Earth's surface. As a result, advancements in GIS, remote sensing, and hydraulic modelling technologies have been actively utilized in developing models that are widely used around the globe for disaster risk reduction [12][13]. This technique has many benefits, including ease of use, low cost, adaptability to environmental models, and coverage of a large region [14]. Several studies that have been carried out using a GIS approach in the world such as; [15]

\footnotetext{
* Corresponding author: nani.nagu09@gmail.com
} 
about GIS and local knowledge in disaster management: a case study of flood risk mapping in Vietnam; [16] about Application of Remote Sensing and GIS For Flood Risk Analysis: A Case Study At Kalu- Ganga River, Sri Lanka; [17] Assessing and mapping flood hazard, vulnerability, and risk in the Upper Brahmaputra River valley using stakeholders' knowledge and multicriteria evaluation (MCE), and [18] about Geospatial Assessment of Flood Hazard in Jhang District, Pakistan.

The purpose of flood hazard assessment is to determine the likelihood of a flood of a given severity occurring over a prolonged period of time. Hazard assessment seeks to quantify this likelihood across timescales ranging from years to decades in order to inform risk management actions. Intensity is often defined as the product of flood depth and horizontal flood extent; however, additional metrics of intensity, such as flow velocity and flood duration, may be significant depending on the circumstances. Based on previous explanation that the right method in mapping flood-prone areas is with the assist of a Geographic Information System (GIS) application. Therefore, the objectives of this study are to mapping the hazard-prone area and to analyze the flood vulnerability index in Kobe Watershed, Central Halmahera District.

\section{Materials and Methods}

\subsection{Study Site}

Administratively, the Kobe River watershed is very wide covering three districts, namely Central Halmahera Regency, East Halmahera Regency, and Tidore Islands City in North Maluku Province. However, in this study, the Koba River watershed will be reviewed only in the Central Halmahera District which is located in Lelilef Village and Kobe Kulo Village (Fig 1).

Geographically, the Kobe River Basin is located at coordinates $025^{\prime} 12^{\prime \prime}-045^{\prime} 9^{\prime \prime} \mathrm{N}$ and 127 37' 9" - 128 5' $0 "$ E. The Kobe River has a length of about $43 \mathrm{Km}$ with a watershed area of about $775 \mathrm{Km}^{2}$. According to climate data, the average monthly rainfall in the study region is $183 \mathrm{~mm}$, while the average yearly rainfall is $2191 \mathrm{~mm}$. The rainy season generally lasts from December to May, whereas the summer season lasts from June to November.

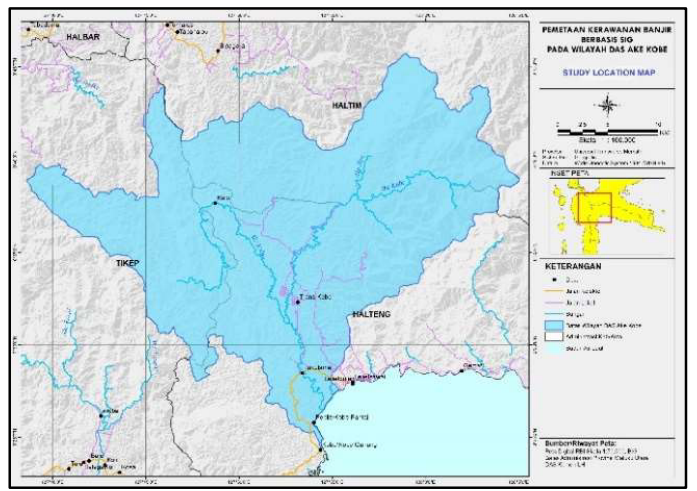

Fig 1. Study Location Map

\subsection{Data Collection and Analysis}

GIS data layers were also used for the study. The flood hazard map was generated by using selected hazard factors. Therefore, vector datasets namely, land use, topography, slope, and rainfall pattern were obtained from several departments. Digital map of the boundary of the Akelamo watershed area obtained from BP DAS Akelamo, North Maluku Province. Rainfall map obtained from satellite data CHIRPS Daily: Climate Hazards Group InfraRed Precipitation with Station Data (version 2.0 final), and verified with data from the closest observation station to the study location. DEM (Digital Elevation Model), using DEM from SRTM (Shuttle Radar Topographic Mission) which has a resolution of $30 \mathrm{~m}$. Land cover data were obtained from the 2019 land cover digital map, the Ministry of Environment, and Forestry's Web GIS. While Soil type map data for soil texture class, which was obtained from a digital map of soil types in North Maluku Province.

Geographical Multi-criteria Decision Analysis (MCDA), image classification, Analytic Hierarchical Process (AHP), and weighted overlay analysis with pairwise comparisons were used to evaluate and map the spatial distribution of flood danger in the research region. As an outcome of the GIS-based multi-criteria hazard analysis, a map was created that allowed for the ranking of hazardous regions [19][20]. Multi-criteria analysis methods based on GIS include the use of a set of assessment criteria represented as map layers. Criteria selection is critical. Each watershed is unique in terms of terrain and hydrology. In general, areas at danger of flooding have certain characteristics, such as topography, slope, land cover, and rainfall pattern. Identifying potentially flood-prone regions by generating maps of five classes of flood vulnerability (from very low to very high).

Data analysis was carried out using a scoring technique for each class in each parameter. The scoring is based on the effect of the class on flooding. The higher the effect on flooding, the higher the score given.

\section{a. Rainfall}

The Thiessen polygon method defines the individual area that is affected by a set of points around it. This polygon is an approach to expanded point information (points become polygons) with the assumption that the best information for all locations without observations is information contained at the closest point where the observations are known, the process uses ArcGIS 9.3 with the extensions create Thissen polygons by entering points coordinates to map. Areas that have high rainfall will have a greater impact on flood events. The scoring is divided into three types of rainfall data, namely daily, monthly and yearly. This study uses daily rainfall data on average rainfall data over a period of one year. The class and score of rainfall showed in table 1 [21]. 
Table 1. Rainfall Class Scoring

\begin{tabular}{|c|c|c|}
\hline No & Class & Score \\
\hline 1 & $>160 \mathrm{~mm}$ & 90 \\
\hline 2 & $141 \mathrm{~mm}-160 \mathrm{~mm}$ & 80 \\
\hline 3 & $121 \mathrm{~mm}-140 \mathrm{~mm}$ & 70 \\
\hline 4 & $101 \mathrm{~mm}-120 \mathrm{~mm}$ & 60 \\
\hline 5 & $81 \mathrm{~mm}-100 \mathrm{~mm}$ & 50 \\
\hline 6 & $61 \mathrm{~mm}-80 \mathrm{~mm}$ & 40 \\
\hline 7 & $41 \mathrm{~mm}-60 \mathrm{~mm}$ & 30 \\
\hline 8 & $20 \mathrm{~mm}-40 \mathrm{~mm}$ & 20 \\
\hline 9 & $<160 \mathrm{~mm}$ & 10 \\
\hline
\end{tabular}

\section{b. Slope}

The slope and elevation were analyzed from DEM SRTM data which was carried out with the help of ArcGIS 9.3 software with Toolbox spatial analysis. The higher the slope, the higher the water carried. Water that is on the land will be forwarded to a lower place faster, compared to land with a low slope. So that the possibility of flooding in areas with a high degree of land slope is getting smaller. The slope class score modified from [21] showed on table 2 .

Table 2. Slope Class Scoring

\begin{tabular}{|l|l|c|c|}
\hline No & \multicolumn{1}{|c|}{ Class } & $\mathbf{\%}$ & Score \\
\hline 1 & Flat & $0-8$ & 90 \\
\hline 2 & Gentle & $8-15$ & 75 \\
\hline 3 & Slightly Steep & $15-25$ & 20 \\
\hline 4 & Steep & $25-45$ & 10 \\
\hline 5 & Very Steep & $>45$ & 0 \\
\hline
\end{tabular}

\section{c. Land Cover}

Land cover will affect the flood susceptibility of an area, land cover will play a role in the amount of runoff water resulting from rain that has exceeded the infiltration rate. Areas that are overgrown with vegetation will find it difficult to drain runoff water due to the large water absorption capacity by vegetation and the slow flow of runoff water due to being held back by tree roots and trunks. The land cover class score modified from [21] showed on table 3 .

Table 3. Land Cover Class Scoring

\begin{tabular}{|c|l|c|}
\hline No & \multicolumn{1}{|c|}{ Land Cover } & Score \\
\hline 1 & Paddy Field & 90 \\
\hline 2 & $\begin{array}{l}\text { Dryland agriculture, settlement, } \\
\text { mining }\end{array}$ & 80 \\
\hline 3 & Shrubs, & 50 \\
\hline 4 & Plantations & 30 \\
\hline 5 & Forest & 10 \\
\hline
\end{tabular}

\section{d. Soil Texture}

Soils with very fine textures have a high chance of flooding, while coarse textures have a low chance of flooding. The scoring for areas that have a very fine soil texture is getting higher. The textire of soil class score modified from [21] showed on table 4 .
Table 4. Texture of Soil Class Scoring

\begin{tabular}{|c|l|c|}
\hline No & \multicolumn{1}{|c|}{ Class } & Score \\
\hline 1 & Very Smooth & 90 \\
\hline 2 & Smooth & 75 \\
\hline 3 & Medium & 50 \\
\hline 4 & Rough & 25 \\
\hline 5 & Very Rough & 10 \\
\hline
\end{tabular}

e. Flood Vulnerability Analysis

The first step in analysing the level of flood susceptibility is to calculate the weight of each parameter. Weighting is giving a weight on a digital map to each parameter that affects the flood, based on the consideration of the effect of each parameter on the occurrence of flooding. The greater the influence of these parameters, the higher the weight given. The weighting for each parameter is presented in table 5 [21].

Table 5. Weight score for Flood Parameters

\begin{tabular}{|c|l|c|}
\hline No & \multicolumn{1}{|c|}{ Parameters } & Weight \\
\hline 1 & Rainfall & 30 \\
\hline 2 & Land cover & 20 \\
\hline 3 & Slope & 20 \\
\hline 4 & Soil Texture & 20 \\
\hline 5 & Elevation & 10 \\
\hline
\end{tabular}

Furthermore, the calculation of the value of an area's vulnerability to flooding is determined from the total score of all parameters that affect flooding. The value of vulnerability is determined using the following equation:

Where:

$$
K=\sum_{i=1}^{n}\left(W_{i} \times X_{i}\right)
$$

$K=$ Vulnerability value

$W i=$ Weight for parameter $i$

$X i=$ Class score on parameter $i$

The determination of the level of vulnerability is done by dividing the number of vulnerability values equally by the number of class intervals using the following equation [21];

$$
\mathrm{i}=\mathrm{R} / \mathrm{n}
$$

where:

$i=$ Width of interval

$R=$ The difference between the maximum and minimum scores

$n=$ Number of flood susceptibility classes

Areas that are very prone to flooding will have a high total value, whereas areas that are not prone to flooding will have a low total value. The criteria of flood vulnerability were determined in table 6 . 
Table 6. Flood Vulnerablity Score

\begin{tabular}{|c|l|c|}
\hline No & Vulnerability Level & Score \\
\hline 1 & Very High Vulnerable & $>67,5$ \\
\hline 2 & Vulnerable & $45-67,5$ \\
\hline 3 & Moderate & $22,5-44$ \\
\hline 4 & Low & $<22,5$ \\
\hline
\end{tabular}

\section{Result and Discussion}

Rainfall, slope, land cover, soil texture, and elevation were identified as the main flood-generating variables in the study region during the flood hazard assessment. The flood-generating raster layers have been categorized according to the area's flood capacity. Accordingly, all variables have been categorized into four categories depending on their sensitivity to flooding: low, moderate, high susceptible, and very highly vulnerable. The following table summarizes the findings of the flood hazard factor study.

\subsection{Rainfall Pattern}

The quantity of runoff is inversely proportional to the amount of rainfall received in a given region. When a region gets significant rainfall, the water level increases over the riverbanks and begins to overflow, resulting in flooding [22]. According to [23] floods are mostly caused by rainfall in the catchment's middle portions, and locations in lower basin catchments are particularly vulnerable to flooding.

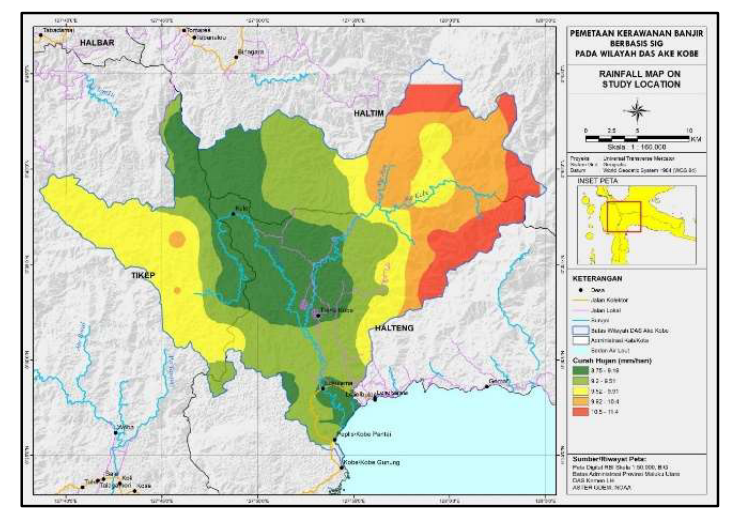

Fig 2. Rainfall Map on Study Location

The result of rainfall analysis showed on map that obtained from the processing of rainfall data in 2020, where the maximum rainfall is $93.9 \mathrm{~mm}$ with a total annual rainfall of $1112.3 \mathrm{~mm} /$ year, categorized as normal. In addition, based on the rainfall map, it can be seen that the upstream part of the Kobe watershed is more dominated by $8.75-10.4 \mathrm{~mm} /$ day of rainfall. Meanwhile, in the downstream area, rainfall is 9.2-8.51 $\mathrm{mm} /$ day. The rainfall map showed in Fig. 2.

\subsection{Slope}

The slope was also identified a major contributor to flood risks in the research region, since it plays a critical role in influencing the pace and duration of water flow. For example, flat surface regions are more dangerous than steep surface areas in terms of flood occurrence [24][25][19].

The percent of the slope in the study area has displayed the range between the highest slope of $45 \%$ and the lowest slope of $0 \%$. As a result, regions with the lowest slope values $(0-3 \%)$ were classified as having a very high flood danger slope angle and subsequently rated to class 5 . In the case of the slope, regions with the greatest slope values (>15\%) were classified as having a very low flood danger slope angle and were therefore assigned a class 1 ranking (Table 7).

The Kobe watershed's slope is classified into five groups. The mapping findings indicate that $64 \%(52,357$ ha) of the slopes at the research site are flat, $34 \%(27,876$ ha) are gently, and the remainder are steep to extremely steep. The map of slope on study areas showed in Fig. 3.

Table 7. Slope Categories on study Area

\begin{tabular}{|l|l|c|c|}
\hline No & \multicolumn{1}{|c|}{ Class } & Area (Ha) & \% \\
\hline 1 & Flat & $52,357.34$ & 64 \\
\hline 2 & Gentle & $27,876.30$ & 34 \\
\hline 3 & Slightly Steep & $1,188.58$ & 1,5 \\
\hline 4 & Steep & 3.99 & 0,8 \\
\hline 5 & Very Steep & 1.61 & 0,2 \\
\hline
\end{tabular}

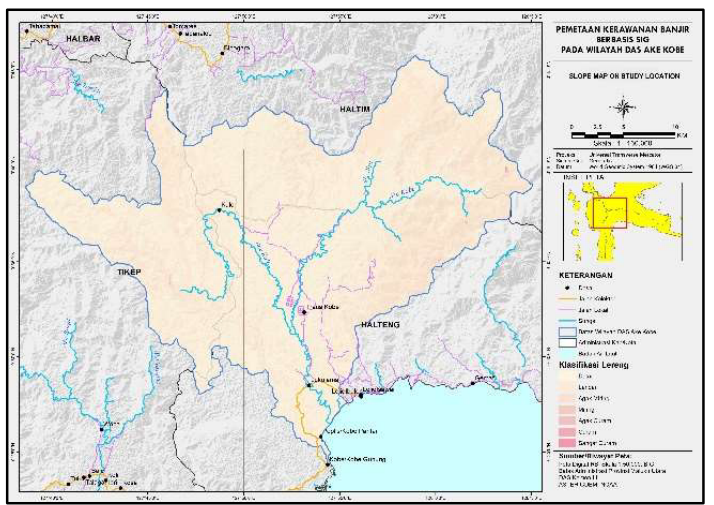

Fig 3. Slope Map on Study Location

\subsection{Land Cover}

The study mainly revealed that land use was the main flood hazard contributing factor in the study area. Landuse types of the study area were forests, forest plantation, mining area, mangrove forest scrublands, transmigration/residential areas, paddy field, open ground and water bodies. According to the land cover analysis, the dryland forest (primary and secondary) was dominated in study area $77 \%$ or 62,240 ha followed by scrub $13 \%(10,942 \mathrm{ha})$. the least land covered by residential area/transmigration $0.11 \%$ (95 ha). the result of land cover analysis and its percentage showed in table 8 , while the land cover map showed in fig. 4 . 
Table 8. Land Cover Categories on study Area

\begin{tabular}{|l|l|r|c|}
\hline No & Land Cover & \multicolumn{1}{|c|}{ Area (Ha) } & \multicolumn{1}{c|}{} \\
\hline 1 & Secondary Dryland Forest & $51,322.23$ & 63.025 \\
\hline 2 & Scrub & $10,942.19$ & 13.437 \\
\hline 3 & Primary Dryland Forest & $10,918.46$ & 13.408 \\
\hline 4 & Open Ground & $3,843.00$ & 4.719 \\
\hline 5 & Mixed Farming & $3,351.06$ & 4.115 \\
\hline 6 & Mangrove Forest & 287.77 & 0.353 \\
\hline 7 & Mining Area & 284.68 & 0.350 \\
\hline 8 & Paddy Field & 387.71 & 0.476 \\
\hline 9 & Residential area & 95.00 & 0.117 \\
\hline & Total Area & $\mathbf{8 1 , 4 3 2 . 1 0}$ & $\mathbf{1 0 0 . 0 0 0}$ \\
\hline
\end{tabular}

Numerous studies have shown that residential areas are more likely to have a high rate of surface runoff than vegetated regions. Forest and scrublands, in particular, significantly decrease the effect of rainfall and the quantity of water that ends up as surface runoff. Waterresistant surfaces such as buildings, concrete, paved areas, and roads in settlement zones reduce water penetration into the soil and increase surface runoff [25]. In addition, land use features had a major role in determining potential flood hazard regions as well as susceptibility to flood risk [25]. Thus, it is possible to identify a substantial shift in the downstream of the Kelani River basin about which land-use type is the primary contributor to flood hazards in the research region based on their impact on floods.

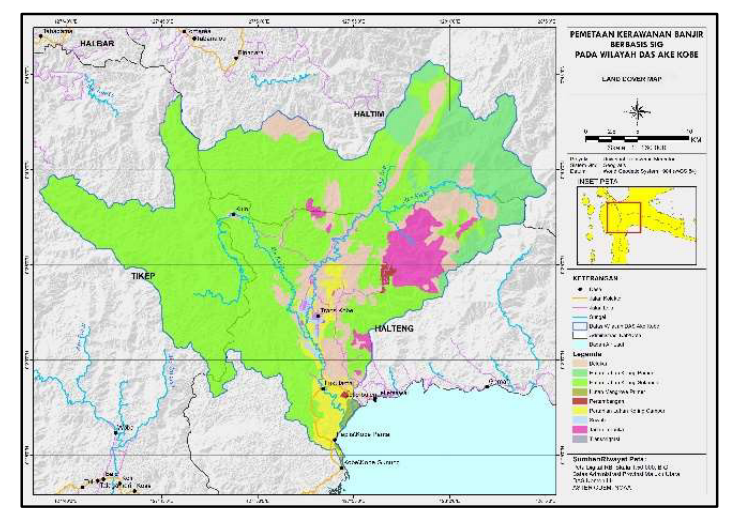

Fig 5. Land Cover Map on Study Location

\subsection{Soil Texture}

The research discovered that the impact of soil type on the study area's flood danger is the least significant of all flood causing variables. Floods, in particular, are more likely to occur on saturated soils, implying that both soil moisture condition and precipitation intensity are critical [26].

The study revealed that the soil texture in Weda subdistrict is dominated by medium class. This soil type was covered by $87.49 \%\left(128.2 \mathrm{~km}^{2}\right)$ of the total extent downstream of the Kobe River basin. Followed by $12.29 \%\left(18.01 \mathrm{~km}^{2}\right)$ is a soil texture with fine grade, and the rest $0.23 \%\left(0.33 \mathrm{~km}^{2}\right)$ is in the form of river water. The study also revealed that this soil texture lied in a high probability of occurrence of floods (Table $9 \&$
Figure 6) of which surface runoff was more dominant in the hard laterite than the water infiltration.

Tabel 9. Soil Texture in Study Location

\begin{tabular}{|c|c|c|c|}
\hline No & Soil Texture & Area $\left(\mathbf{K m}^{\mathbf{}} \mathbf{)}\right.$ & $\mathbf{\%}$ \\
\hline 1 & Very Fine & - & - \\
\hline 2 & Fine & 18.01 & 12.29 \\
\hline 3 & Medium & 128.20 & 87.49 \\
\hline 4 & Coarse & - & - \\
\hline 5 & Very Coarse & - & - \\
\hline 6 & Water & 0.33 & 0.23 \\
\hline & Total & 146.54 & 100.00 \\
\hline
\end{tabular}

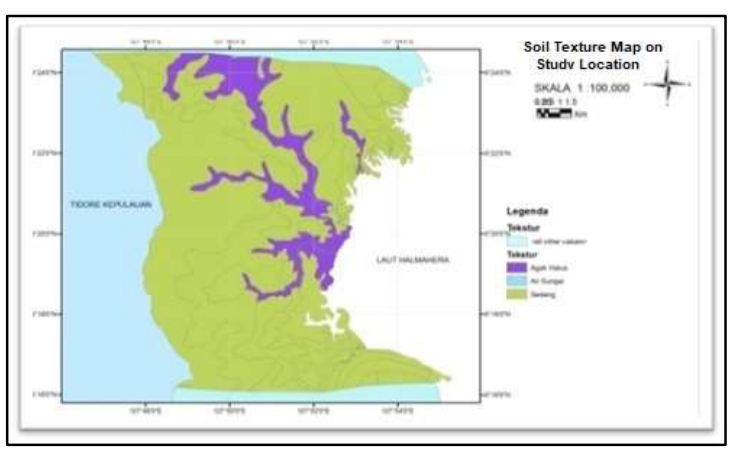

Fig 6. Soil Texture Map on Study Location

\subsection{Elevation}

The first-order control on the spatial variance of hydrological conditions is topography [27]. The Digital Elevation Model (DEM) is one of the primary elements that contribute to flooding, since lower altitudes assume a greater flood hazard potential. Because runoff moves from high to low terrains, the risk of flooding in lowelevated areas is greater [28]. According to [29] that low-lying areas are more susceptible to flooding, since they may be flooded by even minor floods. As a result, the middle portions of the study area that are lowest in elevation ( $0-100 \mathrm{~m}$ above sea level) are most susceptible to flooding (Figure 7). On the other side, the eastern and western areas are the highest in elevation (500-1500m above sea level) and are the least prone to flooding.

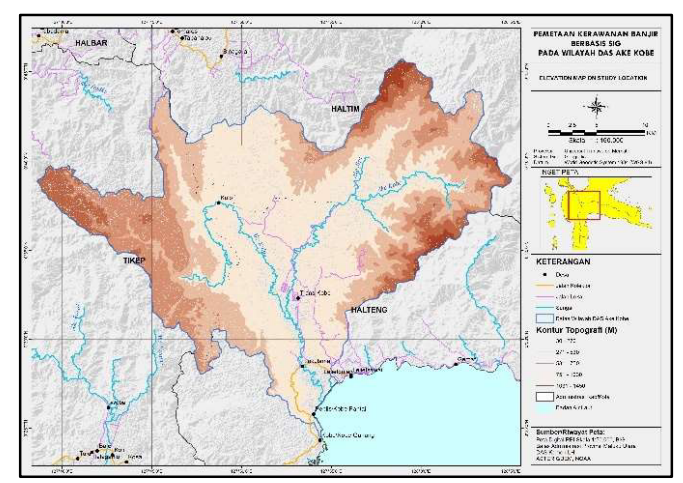

Fig 7. Elevation Map on Study Location 


\subsection{Flood Vulnerability}

Weighted overlay analysis was utilized as a multicriteria assessment method to determine the flood hazard or likelihood of flooding in the research region [30]. The six variables listed above were compared to one another in terms of their contribution to flood danger [25][24]. In other words, the flood hazard assessment map was created utilizing GIS in conjunction with multi-criteria AHP methods and a weighted overlay to account for flood-generating variables like as slope, elevation, rainfall, land cover, and soil texture downstream of the Kobe River basin.

As a result, the flood hazard assessment map (Figure 8) indicates that only $40 \%$ of the study area was inside high or very high danger zones (Table 10). Additionally, the research discovered that the majority of the study region (26,97 percent) is located in a moderate danger zone. While 32,23 percent $(2,053 \mathrm{Ha})$ of the research region was classified as having a very low risk of flooding.

Table 10. The area covered by flood hazardous levels

\begin{tabular}{|c|l|c|c|}
\hline No & Vulnerability Level & Area (Ha) & \% \\
\hline 1 & Low & $2,053.63$ & 32.23 \\
\hline 2 & Moderate & $1,718.45$ & 26.97 \\
\hline 3 & Vulnerable & $1,626.27$ & 25.52 \\
\hline 4 & Very High Vulnerable & 972.99 & 15.27 \\
\hline & Total & $\mathbf{6 , 3 7 1 . 3 4}$ & $\mathbf{1 0 0 . 0 0 0}$ \\
\hline
\end{tabular}

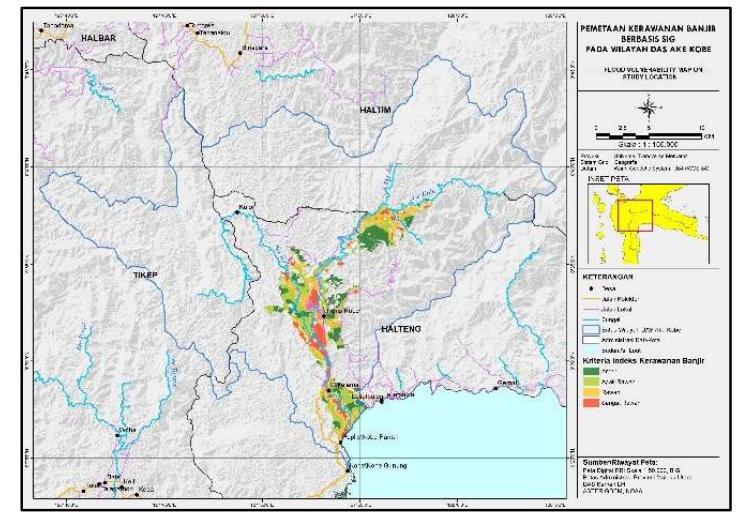

Fig 8. Flood Vulnerability Map on Study Location

\section{Conclusion}

Overall, the District of Weda is a flood-prone area, with 77.46 percent of its land classified as less prone to flooding and 21.41 percent classified as flood-prone. However, only 21.41 percent of its land is classified as flood-prone. Only 1.13 percent of the land is protected from the danger of floods, compared to the whole country. The altitude factor is the most important element influencing flood susceptibility in Weda District, where the majority of the land (16.34 percent) is located at or below sea level, making it particularly vulnerable to flooding. When it comes to describing a flood-prone region in the form of a map that includes variables that influence flooding, Geographic Information Systems (GIS) excel.

\section{References}

[1] W. Kron, "Flood risk = hazard - values • vulnerability," Water Int., vol. 30, no. 1, pp. 5868, (2005), doi: 10.1080/02508060508691837.

[2] K. Ali, R. M. Bajracharya, and H. L. Koirala, “A Review of Flood Risk Assessment," Int. J. Environ. Agric. Biotechnol., vol. 1, no. 4, pp. 1065-1077, (2016), doi: 10.22161/ijeab/1.4.62.

[3] A. M. J. De Kraker, "Flooding in river mouths: Human caused or natural events? Five centuries of flooding events in the SW Netherlands, 15002000," Hydrol. Earth Syst. Sci., vol. 19, no. 6, pp. 2673-2684, (2015), doi: 10.5194/hess-192673-2015.

[4] I. M. Magami, S. Yahaya, and K. Mohammed, "Causes and consequences of flooding in Nigeria: a review CAUSES AND CONSEQUENCES OF FLOODING IN NIGERIA : A REVIEW," Biol. Environ. Sci. J. Trop., vol. 11, no. June, pp. 154-162, (2014).

[5] G. Schädler et al., "Flood Hazards in a Changing Climate," Clim. Res., p. 86, (2012), [Online]. Available: file:///C:/PDF_Mendeley/Flood_Hazards_in_a _Changing_Climate.pdf.

[6] $\bar{A}$. Miradj and S. Rahman, "Analisis Debit Banjir Sungai Uru Ino, Kabupaten Halmahera Timur Menggunakan Pendekatan Hidrograf Satuan Sintetis ( Hss ) Gamma I Dan Hss," vol. 13, no. 1, pp. 1-13, (2020).

[7] J. I. T. Moreng, M. Murdiyanto, and H. V. Oroh, "Analisis Kerentanan Banjir di Daerah Aliran Sungai (DAS) Mede Kabupaten Halmahera Utara," J. Episentrum, vol. 1, no. 2, p. 12, (2020), doi: 10.36412/jepst.v1i2.2122.

[8] F. Paper, Z. K. Misbah, E. R. Ahadian, and U. Khairun, "Jurnal of Science and Engineering BANJIR,” pp. 1-13, (2020).

[9] Y. A. Priambodo and K. M, "Jurnal SIPILsains," J. Sipilsains, vol. 10, no. 2 September, pp. 151-156, (2020), [Online]. Available:

http://ithh.journal.ipb.ac.id/index.php/p2wd/arti cle/view/22930.

[10] D. Rivaldy, T. J.-J. S. STATIK, and undefined 2018, "Evaluasi Kapasitas Penampang Sungai Tugurara Kota Ternate Terhadap Debit Banjir," Ejournal.Unsrat.Ac.Id, vol. 7, no. 9, pp. 11591169, (2019), [Online]. Available: https://ejournal.unsrat.ac.id/index.php/jss/articl e/view/19862.

[11] M. R. Lessy, N. Nagu, M. Rizal, N. Wahiddin, and U. Khairun, "Flood Risk Assessment and Its Vulnerability in Coastal Villages, Central Halmahera District-North Maluku Marine Resources Management," 2018. 
[12] C. Armenakis, E. X. Du, S. Natesan, R. A. Persad, and Y. Zhang, "Flood risk assessment in urban areas based on spatial analytics and social factors," Geosci., vol. 7, no. 4, pp. 1-15, (2017), doi: 10.3390/geosciences7040123.

[13] S. Zlatanova, T. Ghawana, A. Kaur, and J. M. M. Neuvel, "Integrated flood disaster management and spatial information: Case studies of netherlands and India," Int. Arch. Photogramm. Remote Sens. Spat. Inf. Sci. ISPRS Arch., vol. XL-8, no. 1, pp. 147-154, (2014), doi: 10.5194/isprsarchives-XL-8-147(2014).

[14] A. Gharagozlou, H. Nazari, and M. Seddighi, "Spatial Analysis for Flood Control by Using Environmental Modeling," J. Geogr. Inf. Syst., vol. 03, no. 04, pp. 367-372, (2011), doi: 10.4236/jgis.2011.34035.

[15] P. Tran, R. Shaw, G. Chantry, and J. Norton, "GIS and local knowledge in disaster management: a case study of flood risk mapping in thua thien hue province, Vietnam," Disasters, vol. 33, no. 1, pp. 152-169, (2008), [Online]. Available:

http://web.a.ebscohost.com.recursosbiblioteca. eia.edu.co/ehost/pdfviewer/pdfviewer?vid=5\&s $\mathrm{id}=4156 \mathrm{fa} 22-6825-43 \mathrm{ac}-$ add 7 -

495761bf50ba\%40sdc-v-sessmgr01.

[16] S. S. M. J. S, N. H. K, W. D. P, F. J. S. M, H. M. K, and S. L, "Application of Remote Sensing and Gis for Flood Risk Analysis : a Case Study At Kalu- Ganga River, Sri Lanka," Int. Arch. Photogramm. Remote Sens. Spat. Inf. Sci., vol. XXXVIII, no. 8, pp. 110-115, (2010).

[17] N. Hazarika, D. Barman, A. K. Das, A. K. Sarma, and S. B. Borah, "Assessing and mapping flood hazard, vulnerability and risk in the Upper Brahmaputra River valley using stakeholders' knowledge and multicriteria evaluation (MCE)," J. Flood Risk Manag., vol. 11, pp. S700-S716, (2018), doi: 10.1111/jfr3.12237.

[18] K. M, R. O, S. A, N.-U.-Mi. M, and H. M. N, "Geo Spatial Assessment of Flood Hazard in Jhang District, Pakistan," J. Basic Appl. Sci., vol. 13, pp. 577-582, (2017), doi: 10.6000/1927-5129.2017.13.93.

[19] A. Rimba, M. Setiawati, A. Sambah, and F. Miura, "Physical Flood Vulnerability Mapping Applying Geospatial Techniques in Okazaki City, Aichi Prefecture, Japan," Urban Sci., vol. 1, no. 1, p. 7, (2017), doi: 10.3390/urbansci1010007.

[20] I. Ahmad and M. Dar, "Flood Hazard Mapping Using Exploratory Regression Model in GIS Domain."

[21] G. Damar Pandulu, "Analisis Dan Pemetaan Daerah Kritis Rawan Bencana Wilayah Uptd Sda Turen Kabupaten Malang," J. Reka Buana, vol. 1, no. 2, pp. 73-78, (2015).

[22] R. Few, M. Ahern, F. Matthies, and S. Kovats, "Floods, health and climate change: a strategic review," East, no. November, p. 138 pp., (2004), [Online]. Available: http://www.tyndall.ac.uk/publications/working _papers/wp63_summary.shtml\%5Cnhttp://tynd all.ac.uk/sites/default/files/wp63.pdf.

[23] P. Hettiarachchi and S. Lanka, "Hydrological Report on the Kelani River Flood in May 2016 Hydrological Report on the Kelani River Flood in May 2016," no. May 2016, (2020).

[24] L. Gigović, D. Pamučar, Z. Bajić, and S. Drobnjak, "Application of GIS-interval rough AHP methodology for flood hazard mapping in Urban areas," Water (Switzerland), vol. 9, no. 6, pp. 1-26, (2017), doi: 10.3390/w9060360.

[25] G. S. Ogato, A. Bantider, K. Abebe, and D. Geneletti, "Geographic information system (GIS)-Based multicriteria analysis of flooding hazard and risk in Ambo Town and its watershed, West shoa zone, oromia regional State, Ethiopia," J. Hydrol. Reg. Stud., vol. 27, no. November 2019, p. 100659, (2020), doi: 10.1016/j.ejrh.2019.100659.

[26] S. I. Seneviratne et al., "Changes in climate extremes and their impacts on the natural physical environment," Manag. Risks Extrem. Events Disasters to Adv. Clim. Chang. Adapt. Spec. Rep. Intergov. Panel Clim. Chang., vol. 9781107025, pp. 109-230, (2012), doi: 10.1017/CBO9781139177245.006.

[27] T. T. An, V. Raghavan, N. V. Long, S. Izuru, and N. Tsutsumida, "A GIS-based Approach for Flood Vulnerability Assessment in Hoa Vang District, Danang City, Vietnam," IOP Conf. Ser. Earth Environ. Sci., vol. 652, no. 1, (2021), doi: 10.1088/1755-1315/652/1/012003.

[28] H. Allafta and C. Opp, "GIS-based multicriteria analysis for flood prone areas mapping in the trans-boundary Shatt Al-Arab basin, IraqIran," Geomatics, Nat. Hazards Risk, vol. 12, no. 1, pp. 2087-2116, (2021), doi: 10.1080/19475705.2021.1955755.

[29] M. Rahman et al., "Flood Susceptibility Assessment in Bangladesh Using Machine Learning and Multi-criteria Decision Analysis," Earth Syst. Environ., vol. 3, no. 3, pp. 585-601, (2019), doi: 10.1007/s41748-019-00123-y.

[30] K. K. E. Perera, "Flood Hazard Assessment Using Gis-Based Multi- Criteria Analysis : A Case Study From Downstream Of Kelani River Basin , Sri Lanka," vol. 3, no. 1, pp. 50-68, (2021). 